the positron provided the final proof of the validity of Dirac's theory of the electron, for this theory requires the existence of just such a particle.

Dr. Anderson has also contributed greatly to the study of cosmic radiation itself, particularly by his work on the energy spectrum of the rays and of their energy loss in passing through matter. In connexion with the latter, he has recently shown that electrons with energies at least up to $3 \times 10^{8}$ electron volts do suffer the large radiation energy losses which are predicted by theory. During the last year, Dr. Anderson took his apparatus to the top of Pike's Peak at an altitude of 4,300 metres, and there obtained a large number of cosmic ray photographs by the counter-controlled method. Among these are some of the finest shower photographs yet taken. It is interesting to note that Dr. Anderson's communication to Science, announcing the apparent existence of a positive electron, was only the fourth paper published by him. Dr. Anderson, who is only thirty-one years of age, must certainly be the youngest experimenter in recent decades to make a discovery of such first-class importance; and now he is also to be congratulated on being surely one of the youngest experimental physicists to receive a Nobel prize.

\section{Edward Meyrick, F.R.S.}

Mr. Foward MeYrick will reach the age of eighty-two years on November 24, and his many friends and correspondents all over the world will join with NATURE in good wishes and congratulations on his effective life's work. In 1927, when awarded the Captain Scott Memorial Medal by the South African Biological Society, for his study of South African Microlepidoptera, the president justly remarked that "Mr. Meyrick's is an example of what can be done by a single individual, unsupported, with no financial backing, but devoted to a task that fills his life". Meyrick is a Wiltshireman, still residing at Thornhanger, Marlborough. He was a boy at Marlborough College from 1868 until 1873, and a classical scholar of Trinity College, Cambridge. From 1877 until 1886 he was a schoolmaster at Sydney, Australia, and at Christchurch in New Zealand. He returned to Marlborough College as an assistant master in 1887 and continued there until his retirement in 1914. During the last fifteen years of that period, he was president of the Marlborough College Natural History Society, which has been an inspiration to so many young naturalists, many of them now men of distinction. Marlborough is indeed one of the most fortunate of schools, situated in the beautiful valley of the Kennet between Savernake Forest and the wide and open chalk downs of Wiltshire, with its varied fauna and flora. The country-side is famous for dykes, barrows and hill-forts, and the county contains Stonehenge, Avebury, Old Sarum and Silbury; while the British 'mount' of Marlborough stands within the historic grounds of the College, once a British fort, once a castle, once a mansion, once the "Castle Inn" with its memories of Pitt, now a school, and always famous.
The duties of an assistant master at a public school are so arduous and exacting that it is rather rare for a schoolmaster to achieve the distinction of becoming a fellow of the Royal Society. Meyrick was elected in 1904, largely for his work on Australian Lepidoptera. About nine years later he published his "Handbook of British Lepidoptera" (Macmillan), and in 1927 "A Revised Handbook of British Lepidoptera" (Watkins and Doncaster). In these books Meyrick broke away from the older classification based on fugitive characteristics such as wing patterns and colours, and he depended largely, but not entirely, on the more permanent forms of the veins or neurations of the wings. He was familiar with the MicroIepidoptera of South Africa, Australia and New Zealand, for he was a great traveller, and a student of the moths and butterflies of the whole world. His study of the insects of Australia and New Zealand caused him to reject the Wegener hypothesis that those regions, once united, had drifted a thousand miles apart. Meyrick had a large viewpoint as a naturalist, and the following have been termed, by Comstock, Meyrick's Laws, though perhaps laws is not quite the right word: "No new organ can be produced except as a modification of some previously existing structure." "A lost organ cannot be regained." "A rudimentary organ is rarely re-developed." Most of Meyrick's work will be permanent; other work has come and more will originate from the many pupils to whom he has handed on the lamp of wisdom and the torch of enthusiasm.

\section{Dr. F. Simon}

Dr. F. Simon, who has been appointed to succeed Prof. A. C. G. Egerton as reader in thermodynamics at Oxford (see p. 895), took his degree in Berlin in 1921. He was Privatdozent and extraordinary professor of physics there until 1931. From 1931 until 1933 he was director of the physical-chemical institute of the University of Breslau. He was in California for six months in 1932 as a visiting professor. During the last three years he has been working in the Clarendon Laboratory at Oxford on low temperature research, particularly on the production of very low temperatures by the magnetic cooling method, and on the properties of matter in the neighbourhood of the absolute zero.

\section{J. L. Macadam (1756-1836)}

THE centenary of the death of John Loudon Macadam, which occurs on November 26 (see p. 869), is a reminder of the debt we owe to that group of men who at a critical time in our industrial history were instrumental in making vast improvements in our means of transport. As one of this group, Macadam has a place beside Brindley, the Duke of Bridgewater, Telford, Rennie, Metcalf, Smeaton and others. Macadam was born in Ayr on September 23, 1756. $\mathrm{He}$ lost his father in 1770 and as a boy of fourteen years of age was sent to an uncle in New York. Thirteen years later he returned home comparatively well off, and settled down to the life of a country gentleman in his native country. It was as such 
he began his experiments on road-making, which were eventually to bring him fame if not fortune. It is not a little extraordinary, however, that his main work was done after reaching the age of sixty years, when he was made surveyor-general of roads to the Bristol Turnpike Trust. He resigned this position when sixty-nine, and two years later Parliament appointed him Surveyor-General of Roads. This position he held until his death at Dumcrieff House, Moffat, on November 26, 1836. At one time it is said he had no fewer than three hundred surveyors working under him. The importance of his work was fittingly commemorated at Ayr on October 30 last, when a bronze tablet erected by the Institution of Municipal and County Engineers was unveiled by Mr. Hore-Belisha, the Minister for Transport, and a paper on "John Loudon Macadam, Roadmaker" was read by Mr. G. S. Barry, the County Surveyor, Ayrshire.

\section{Memorial to the late Sir Walter Fletcher}

ON November 11, the subscribers to the Sir Waiter Fletcher Memorial Fund were invited by the Medical Research Council to view Miss Dora Clarke's portraitbust of the late Sir Walter Morley Fletcher, secretary of the Council from 1914 until 1933. The ceremony was held at the National Institute for Medical Research, Hampstead, in the library of which the bust is to be placed permanently. Lord Balfour of Burleigh, chairman of the Council, presided. The chief speakers were Prof. G. M. Trevelyan and Sir Frederick Gowland Hopkins, the former dealing mainly with the personal aspect and the latter with Fletcher's scientific and administrative work. Sir Henry Dale, director of the Institute, then accepted eustody of the bust. The total amount contributed to the Fund by more than five hundred separate subscribers is approximately $£ 2,300$. The remainder, after meeting the cost of the personal memorial, is being used for a Walter Fletcher Memorial Laboratory. This is being constructed at the Farm Laboratories of the National Institute at Mill Hill, and is to be used for research work in nutrition.

\section{Grassland of Great Britain}

AT a meeting of the Engineers Study Group on Economics held on November 10, Prof. R. G. Stapledon discussed methods of dealing with the problem of grassland in Great Britain. He exhibited a map of Wales, the result of a recent survey, and pointed out that there are only 16,000 acres of proper pastures (rye grass), although at least a third of the 153,000 acres under bracken is of high potential value. To make the best use of the $18,000,000$ acres of rough hill grazing ground in Great Britain, Prof. Stapledon considers that it is necessary for the State to acquire and develop it. This, he believes, would be economically feasible over a period of 25-50 years, beginning at once with an area of not less than 200,000 acres. Agriculturally, the potentialities of the hill land not above the $150 \mathrm{ft}$. contour (in all, more than $14,500,000$ acres) are enormous, at least 20 per cent of that area being amenable to radical improvement. Lowland grass could be used for drying and for wintering, and improved upland grass for summering, and the plough, oats and fatting crops everywhere. Roads and tracks should be constructed in connexion with land improvement and afforestation. Sir Richard Paget, who presided at the meeting, expressed his appreciation of the pioneer work of Prof. Stapledon, and Lord Northbourne, in opening the discussion, stressed the importance of preserving individual initiative.

\section{Temples and Caste in Travancore}

THE decision of the Maharajah of Travancore, announced by proclamation authorizing the opening of the temples controlled by the State to all Hindus, according to a Delhi dispatch in The Times of November 16, has been hailed by progressive opinion in India as "the greatest reform of Hinduism since Ramanuja's days". By this drastic action, which at once obliterates caste distinction in right of access to the sacred places of religion, and removes one of the most strongly resented marks of inferiority in the outcastes, the State of Travancore has opened a way to political unity which Hinduism at large would do well to accept as a guide and example. The exceptional position of the Rajah in relation to the State religion has endowed him with a power of initiative that was open to few others in India, and perhaps least of all to the British Raj ; but whether the example of Travancore will be followed elsewhere will doubtless depend in no small degree upon the religious and political reaction to so serious an innovation. It is said that conservative opinion has already criticized the reform as rash and unsound, while maintaining that the views of Hinduism outside Travancore should have been considered-a claim, of which, in view of past events, it would be difficult to vindicate the political wisdom. On the other hand, the Nationalists and leading members of the Congress, with Mr. Gandhi, have hastened to congratulate the head of the State of Travancore on his decision.

\section{Guide to Ancient Monuments}

Mr. ORMSBy-Gore's promise on relinquishing office as First Commissioner of Works to complete the manuscript of that part of the official guide to ancient monuments then in hand, has now been redeemed by the publication of the volume covering East Anglia and the Midlands ("Illustrated Regional Guides to Ancient Monuments under the Ownership or Guardianship of H.M. Office of Works", vol. 3, East Anglia and Midlands. By the Right Hon. W. Ormsby-Gore. London: H.M. Stationery Office. Pp. 72. 1s. net). In method of treatment of both the prehistoric and the historic sections this volume follows the plan of its predecessors; but matter of general application in the various periods, which has been given in the earlier volumes, has been omitted. Although it may be agreed that nothing can make a stronger appeal to the historic imagination than Stonehenge and Avebury, which have already been described, the present volume in no other respect falls below those already issued in the importance and interest of the monuments which it includes. As 